\title{
Identifikasi Produktivitas Pengolahan Tuna Beku Pada PT. Maluku Prima Makmur di Kota Ambon
}

\author{
[Identification of Frozen Tuna Processing Productivity at PT. Maluku Prima \\ Makmur in Ambon City]
}

\author{
Alfred Freddy Palyama ${ }^{1}$, Niken Dharmayanti ${ }^{2}$ \\ ${ }^{1}$ Sekolah Usaha Perikanan Menengah Waiheru Ambon \\ ${ }^{2}$ Program Studi Pengelolaan Sumberdaya Perikanan Program Pasca Sarjana Politeknik Ahli Usaha Perikanan \\ Jakarta
}

\begin{abstract}
Abstrak
Ikan tuna (Thunnus $s p$ ) merupakan salah satu hasil tangkapan yang potensial di perairan Maluku. Hasil tangkapan tuna di Maluku pada Tahun 2019 adalah sebesar 49.401,00 ton. Bahan baku ikan tuna di kota Ambon dijual secara lokal dalam bentuk segar dan bentuk olahan beku. Ikan tuna yang diolah dalam bentuk beku telah dipasarkan di dalam negeri maupun sampai ke luar negeri atau pasaran internasional. Salah satu perusahan Tuna beku di Kota Ambon yang telah mengolah ikan tuna dalam bentuk produk tuna beku adalah PT. Maluku Prima Makmur. Penelitian ini bertujuan untuk mengidentifikasi produktivitas pengolahan tuna beku pada PT. Maluku Prima Makmur. Pada penelitian ini, metode yang digunakan adalah metode survei dan pengamatan langsung di lapangan, Analisis data berupa data kuantitatif yang disajikan dalam bentuk tabulasi (diagram dan tabel). Data yang diperoleh dianalisis menggunakan metode kaizen yang dilanjutkan dengan uraian secara deskriptif. Hasil dari penelitian ini adalah poses pengolahan Tuna Beku di PT. Maluku Prima Makmur adalah sebagai berikut: Penerimaan bahan baku ikan Tuna tanpa Insang dan isi perut, Penimbangan 1, Pencucian 1, Penyimpanan Sementara, Pencucian 2, Pemotongan Kepala, Pencucian 3, Pemotongan Loin, Pembuangan Kulit dan Perapihan, Potong (Saku Cut, Cube Cut), Pengemasan 1, Penyemprotan Gas CO, Pendinginan, Penyedotan Gas CO, Sortasi dan Sizeing, Pengemasan Plastik Vakum, Penimbangan 2, Pemvaccuman, Pembekuan, Pendeteksian Logam (Metal Detection), Penimbangan Pengepakan \& Pelabelan, Penyimpanan Beku, Pemuatan. Berdasarkah hasil penelitian kinerja bagian prosesing tuna beku pada PT. Maluku Prima Makmur masih memenuhi standar produktivitas.
\end{abstract}

Kata kunci: pengolahan, PT. Maluku Prima Makmur, tuna beku

\section{Abstract}

Tuna (Thunnus sp) is one of the potential catches in Maluku sea. Tuna catches in Maluku in 2019 were 49,401.00 tons. Tuna raw materials in Ambon city are sold locally in fresh and frozen forms. Tuna processed in frozen form has been marketed domestically as well as to foreign or international markets. One of the frozen tuna companies in Ambon City that has processed tuna in the form of frozen tuna products is PT. Maluku Prima Prosperity. This study aims to identify the productivity of frozen tuna processing at PT. Maluku Prima Prosperity. In this study, the method used is survey method and direct field observation. Data analysis is in the form of quantitative data presented in tabulated form (diagrams and tables). The data obtained were analyzed using the kaizen method followed by a descriptive description. The result of this research is the process of frozen tuna processing at PT. Maluku Prima Makmur are as follows: Receipt of raw materials for tuna fish without gills and entrails, Weighing 1, Washing 1, Temporary Storage, Washing 2, Head Cutting, Washing 3, Loin Cutting, Skin Removal and Tidying, Cut (Saku Cut, Cube) Cut), Packaging 1, CO Gas Spraying, Cooling, CO Vacuuming, Sorting and Sizeing, Plastic Vacuum Packaging, Weighing 2, Vacuuming, Freezing, Metal Detection, Weighing Packing \& Labeling, Freezing Storage, Loading. Based on the results of 
research on the performance of the frozen tuna processing section at PT. Maluku Prima Makmur still meets productivity standards.

Keywords: frozen tuna, processing, PT. Maluku Prima Makmur

Penulis Korespondensi

Alfred Freddy Palyama | alfred.palyama@gmail.com

\section{PENDAHULUAN}

Ikan tuna (Thunnus sp) merupakan salah satu hasil tangkapan yang potensial di perairan Maluku. Hasil tangkapan tuna di Maluku pada Tahun 2019 adalah sebesar 49.401,00 ton (Statistik KKP, 2020)

Ikan tuna sirip kuning merupakan salah satu jenis ikan yang memiliki harga jual yang tinggi dan juga termasuk salah satu jenis ikan yang paling banyak ditangkap di perairan Indonesia. Hal ini disebabkan karena ikan tuna memiliki rasa yang enak. Namun, bagian tubuh ikan tuna berupa daging yang dapat dikonsumsi sebesar $59 \%$ dan bagian yang diukur adalah daging merah dan daging hitam sedangkan sisanya berupa hasil samping yaitu kepala, tulang, sisik dan kulit. (Hadinoto \& Idrus, 2018)

Stansby dan Olcott (1963) dalam (Hadinoto \& Idrus, 2018) menjelaskan bahwa ikan tuna memiliki kadar protein yang tinggi dan kadar lemak yang rendah. Kandungan protein pada ikan tuna berkisar antara 22,6-26,2 gr/100 gr daging ikan, kandungan mineral (besi, kalsium, fosfor, sodium), vitamin A (retinol) dan vitamin B (thiamin, riboflavin dan niasin).

Badan Standardisasi

Nasional, (2015) mengatur tahapan produk olahan tuna loin beku adalah produk olahan hasil perikanan dengan bahan baku tuna segar yang mengalami perlakuan penerimaan bahan baku, penimbangan, penyiangan, pencucian pertama, penyimpanan

sementara/pendinginan, pencucian kedua, pemotongan kepala, pembuatan loin, pembuangan daging hitam, pembuangan kulit, perapihan, penyuntikan karbon monooksida, pendinginan, perapihan ulang, pengemasan, pembekuan, penyimpanan dalam gudang pendingin.

Ikan tuna beku diproduksi melalui tahapan-tahapan proses yang memerlukan sistem rantai dingin dan dilakukan secara cepat, cermat dan memperhitungkan sanitasi dan higiene. Apabila tidak dilakukan dengan baik maka akan berdampak pada penurunan mutu pada produk akhir. Tujuan penelitian adalah untuk mengidentifikasi 
produktivitas pengolahan tuna beku di PT. Maluku Prima Makmur.

\section{BAHAN DAN METODE}

Penelitian ini dilaksanakan pada tanggal 4 Januari sampai dengan tanggal 4 Februari 2021 yang bertempat pada PT. Maluku Prima Makmur di Pulau Ambon. Data primer diambil secara langsung selama kegiatan penelitian, hasil wawancara dengan narasumber yang kompeten di PT. Maluku Prima Makmur serta partisipasi dan pengamatan langsung di lapangan. Data sekunder diperoleh dari literatur, data administrasi perusahaan maupun bersumber data dari internet.

Bahan dan alat yang digunakan dalam memperoleh data dan informasi berupa log book, lembar wawancara, kamera, dan smartphone. Penelitian ini bersifat deskriptif menggunakan metode survei dan pangamatan langsung. Analisis data berupa data kuantitatif yang disajikan dalam bentuk tabulasi (diagram dan tabel). Data yang diperoleh dianalisis menggunakan metode kaizen yang dilanjutkan dengan uraian secara deskriptif.

\section{HASIL DAN PEMBAHASAN \\ Hasil \\ Keadaan Umum PT. Maluku Prima Makmur}

PT. Maluku Prima Makmur merupakan salah satu perusahaan yang berada di Kota Ambon Provinsi Maluku memiliki lokasi yang sangat strategis karena dekat dengan pantai, berada di dekat jalan utama sehingga memiliki kemudahan akses transportasi bahan baku menuju perusahaan maupun akses distribusi produk menuju Bandara Pattimura maupun Pelabuhan Laut. PT Maluku Prima Makmur merupakan perusahaan yang bergerak dalam industri pengolahan ikan dengan produk utama adalah Ikan tuna beku. Beralamat di Jalan Dr. Leimena No. 8A Desa Tawiri, Kecamatan Teluk Ambon, Kota Ambon

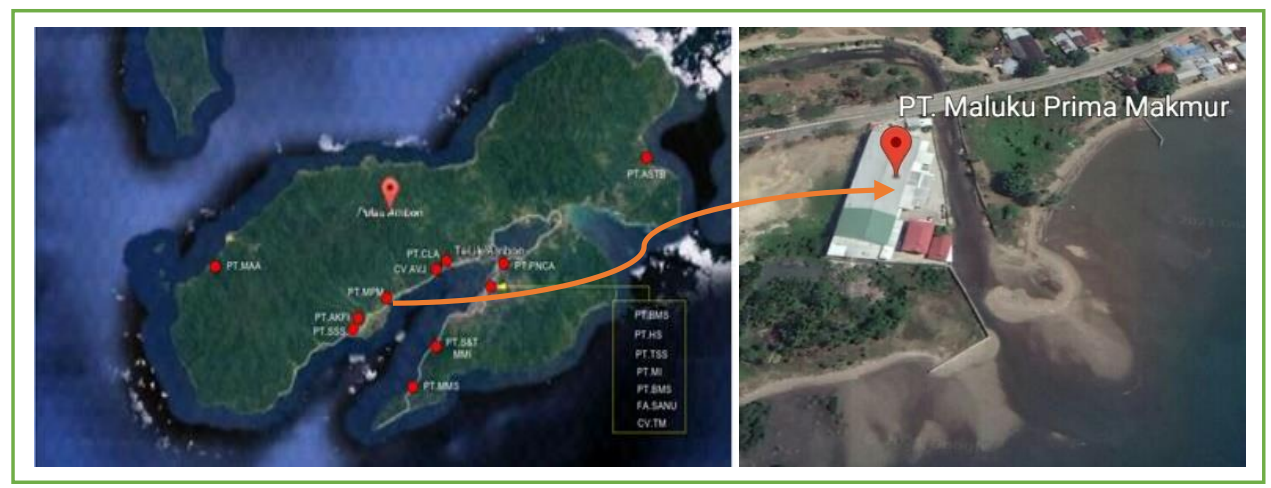

Gambar 1. Denah lokasi PT. Maluku Prima Mamur (Sumber : Google Map) 
Tahapan Proses Pengolahan Tuna Loin Beku

Tahapan proses pengolahan Tuna Loin Beku pada PT. Maluku Prima Makmur dapat diuraikan sebagai berikut:

a. Penerimaan bahan baku

Bahan baku diterima dari supplier dalam bentuk ikan tuna utuh tanpa insang dan isi perut. Pada tahapan ini ikan diterima pada bagian penerimaan bahan baku, dipotong bagian sirip punggung, sirip anal, sirip dada, dan sebagian sirip ekor. Bahan baku kemudian

Tabel 1. Data hasil pengukuran suhu pusat ikan di PT. Maluku Prima Makmur

\begin{tabular}{|c|c|c|c|c|c|c|c|c|c|c|c|}
\hline \multirow{4}{*}{ No } & \multirow{4}{*}{ Uraian } & \multicolumn{9}{|c|}{ Data Suhu Pusat Bahan Baku Ikan Bulan Januari 2021} & \multirow{3}{*}{$\begin{array}{l}\text { Rata- } \\
\text { rata } \\
\text { suhu }\end{array}$} \\
\hline & & \multicolumn{9}{|c|}{ Tanggal Produksi } & \\
\hline & & 4 & 6 & 8 & 11 & 12 & 13 & 14 & 15 & 16 & \\
\hline & & ${ }^{\circ} \mathrm{C}$ & ${ }^{\circ} \mathrm{C}$ & ${ }^{\circ} \mathrm{C}$ & ${ }^{\circ} \mathrm{C}$ & ${ }^{\circ} \mathrm{C}$ & ${ }^{\circ} \mathrm{C}$ & ${ }^{\circ} \mathrm{C}$ & ${ }^{\circ} \mathrm{C}$ & ${ }^{\circ} \mathrm{C}$ & ${ }^{\circ} \mathrm{C}$ \\
\hline 1 & $\begin{array}{l}\text { Rata-Rata } \\
\text { Suhu Bahan } \\
\text { Baku Ikan }\end{array}$ & 1.2 & 2.6 & 1,7 & 1,1 & 2.9 & 2.5 & 1.5 & 1.9 & 2.2 & 1.51 \\
\hline
\end{tabular}

(Sumber : Data Primer PT. MPM)

Tabel 2. Karakteristik mutu tuna dan standar penerimaan

\begin{tabular}{lll}
\hline No & Karakteristik mutu & Standar penerimaan \\
\hline \multirow{2}{*}{$\begin{array}{l}\text { Kesegaran/kecerahan } \\
\text { warna daging }\end{array}$} & $\begin{array}{l}\text { Daging berwarna merah cerah, serat daging } \\
\text { merekat kuat, bentuk potongan daging rapi, } \\
\end{array}$ & $\begin{array}{l}\text { tidak terikut tulang/kulit, dan tidak ada } \\
\text { daging merah }\end{array}$ \\
\hline 2 & Bau & Sangat segar, spesifik jenis \\
\hline 3 & Daging/tekstur & Elastis, padat dan kompak, tidak ada daging \\
\hline 4 & Warna & seperti terbakar (yake) \\
\hline
\end{tabular}

(Sumber : Data Sekunder PT. MPM)

Penimbangan 1 dilakukan untuk

b. Penimbangan 1 mengetahui berat awal ikan Jurnal Penyuluhan Perikanan dan ditangani secara hati-hati, cepat, cermat dan saniter, dilakukan pengecekan suhu pusat ikan tidak melebihi suhu $4,4^{\circ} \mathrm{C}$. Data pengecekan suhu pusat ikan di PT. Maluku Prima Makmur seperti pada Tabel 1. Petugas khusus melakukan uji organoleptic dengan menggunakan alat cecker (coring tube) untuk menentukan mutu/grade ikan. Karakteristik mutu tuna dan standar penerimaan di PT. Maluku Prima Makmur seperti pada Tabel 2. 
pada saat ikan diterima dari supplier serta pencatatan kode supplier

c. Pencucian 1

Setelah ikan ditimbang, ikan dicuci dengan menggunakan air dingin yang mengalir guna menghilangkan kotoran yang menempel pada tubuh ikan, Selanjutnya ikan tuna dimasukan ke dalam bak penyimpanan sementara

d. Penyimpanan Sementara Ikan yang telah dicuci di bagian penerimaan bahan baku, dimasukan ke dalam bak penyimpanan/penampungan

sementara. Pada bak penampungan sementara ikan diberi es curah dan air secukupnya untuk mempertahankan suhu pusat ikan tidak melebihi suhu $4,4^{\circ} \mathrm{C}$, sambil menunggu tahapan prosesing selanjutnya

e. Pencucian 2

Pada tahan ini, ikan dari bak penyimpanan/penampungan sementara diangkat dan dibawa ke meja pencucian ikan tahap 2. Pencucian dilakukan dengan menyikat permukaan tubuh ikan untuk mengeluarkan lendir dan kotoran yang menempel pada tubuh ikan, selanjutnya dilakukan penyiraman dengan menggunakan air dingin yang telah dicampur dengan klorin dengan konsentrasi 100 ppm.

Penggunaan air klorin 100 ppm bertujuan untuk mereduksi bakteri patogen pada permukaan tubuh ikan. Selanjutnya ikan dimasukan ke ruang potong/cutting.

f. Pemotongan kepala

Pada tahapan ini, ikan tuna dipotong bagian kepala dan bagian rongga perut. Pemotongan dilakukan secara cepat dan cermat sehingga daging ikan yang akan dijadikan loin tidak turut terbuang sebagai limbah. Pemotongan kepala dilakukan menggunakan pisau mulai dari pemotongan bagian belakang sirip dada mengikuti arah operculum kebawah sampai pada sirip perut, selanjutnya pemotongan dilakukan dari belakang sirip dada mengikuti arah kepala. Hal ini dilakukan pada posisi yang berlawan setelah ikan dibalik posisinya sehingga kepala ikan akan mudah dilepas dari tubuh ikan. Langkah selanjutnya pemotongan bagian rongga perut dan rongga perut ini akan dijadikan produk yang lain atau bally/toro

\section{g. Pencucian 3}

Pencucian dilakukan dengan menggunakan air dingin yang telah dicampur dengan klorin dengan konsentrasi 100 ppm. 
Penggunaan air klorin 100 ppm

bertujuan untuk mereduksi

bakteri patogen pada

permukaan tubuh ikan,

menghilangkan sisik dan darah

yang menempel pada tubuh

ikan pada tahapan ini.

Selanjutnya ikan dimasukan ke ruang prosesing utama

h. Pengkulitan dan Perapihan

Pada tahap ini loin dilepaskan dari kulitnya kemudian dilakukan pelepasan daging hitam, tulang yang masih tersisa. Selanjutnya dilakukan perapihan loin dengan tujuan membersihkan ikan dari sisa kulit, membuang lapisan lemak yang masih terdapat pada permukaan daging serta kotoran loin yang masih menempel pada saat proses pelepasan kulit (skinning) untuk mencegah kontaminasi.

i. Pemotongan (Saku Cut, Cube Cut)

Pada tahapan ini, bagian loin dipotong menjadi turunannya berupa:

Saku Cut dengan ukuran : L size (panjang $14 \mathrm{~cm} \times$ lebar 20 $\mathrm{cm} \times$ tebal $3 \mathrm{~cm}$ ) dan $M$ size (panjang $20 \mathrm{~cm} \times$ lebar $8 \mathrm{~cm} \mathrm{x}$ tebal $3 \mathrm{~cm}$ )

Cube Cut dengan ukuran : 1,5 x $1,5 \times 1,5 \mathrm{~cm}$ j. Pengemasan dalam plastik vakum

Loin yang sudah rapih dan telah ditentukan mutu dikemas dalam plastik secara individual. Proses ini dilakukan secara cepat, cermat dan saniter serta tetap mempertahankan suhu pusat loin maksimal $4,4^{\circ} \mathrm{C}$. Loin yang telah dimasukan ke dalam plastik diletakkan di keranjang yang telah dialasi dengan jelly ice sehingga suhu dingin loin tetap terjaga sambil menunggu proses selanjutnya

k. Penyemprotan gas $\mathrm{CO}$

Penyemprotan Gas CO (Karbon Monooksida) dimaksudkan untuk memberi warna merah segar pada ikan, dimana gas CO yang disemprotkan akan mengikat mioglobin menjadi karboksimioglobin yang membentuk pigmen berwarna merah.

I. Pendinginan/Chilling

Pendinginan dilakukan selama 2 hari pada suhu ruang chilling antara $-2{ }^{\circ} \mathrm{C}$ sampai dengan 2 ${ }^{\circ} \mathrm{C}$. Pendinginan dimaksudkan agar proses penertrasi gas $\mathrm{CO}$ ke dalam daging ikan tuna merata dan proses pewarnaan menjadi lebih sempurna.

m. Penyedotan Gas CO 
Setelah pendinginan selama 2 hari pada suhu antara $-2{ }^{\circ} \mathrm{C}$ sampai dengan $2{ }^{\circ} \mathrm{C}$, gas $\mathrm{CO}$ disedot kembali dari dalam kantong plastik kemasan dengan menggunakan alat penyedot gas $\mathrm{CO}$.

n. Sortasi dan sizeing

Setelah penyedotan gas $\mathrm{CO}$, produk dikeluarkan dari dalam plastik kemasan kemudian dilakukan sortasi dan sizeing untuk mendapatkan produk yang bermutu baik.

o. Pengemasan plastik vaccum

Produk dikemas menggunakan plastik vaccum dengan jenis HDPE sebelum dilakukan pemvaccuman.

p. Penimbangan 2

Penimbangan pada tahapan ini dimaksudkan untuk mengetahui berat masing-masing loin dan dicatat serta digunakan untuk data label yang akan ditempelkan pada plastk kemasan secara individual

q. Pemvakuman

Pada tahapan ini loin divaccum menggunakan mesin vaccum dengan tekanan pemvaccuman sebesar $80 \mathrm{kPa}$ selama 35 sampai 40 detik serta lama sealing sesuai dengan spesifikasi dari mesin vaccum yang digunakan. Tujuan dari pengemasan vaccum ini adalah selain memberikan keadaan vaccum sehingga loin terhindari dari kemungkinan oksidasi akibat reaksi dengan oksigen, juga memberikan perlindungan terhadap produk loin dari kemungkinan kontaminasi dari luar.

r. Pembekuan

Setelah proses pemvaccuman, loin dibekukan menggunakan mesin pembekuan cepat seperti Air Blast Freezer (ABF), Contact Plate Freezer (CPF) dan Brine Freezer. Pembekuan dilakukan sampai suhu pusat loin mencapai suhu $-30{ }^{\circ} \mathrm{C}$, sesuai dengan kemampuan mesin pembekuan yang digunakan. Suhu ini dapat dicapai selama 7-8 jam pembekuan. Proses pembekuan dimaksudkan untuk menghentikan aktivitas bakteri dan enzim yang merupakan faktor utama pembusukan ikan.

s. Pendeteksian Logam

Setelah proses pembekuan, loin dikeluarkan dari mesin pembekuan dan dilewatkan pada mesin pendeteksi logam/metal detector untuk memastikan bahwa loin yang telah dikemas dan dibekukan benar-benar terbebas dari kontaminan logam yang dapat terjadi akibat kelalaian kerja pada tahapan-tahapan prosesing sebelumnya seperti peniti, pecahan logan dari pisau 
yang digunakan, cincin, asesoris

berbahan logam yang

digunakan oleh pekerja. Apabila

loin yang terdeteksi

mengandung logam maka loin

diproses lebih lanjut dengan

melepas plastik kemasan,

melakukan thawing kembali dan

memeriksa kontaminan logam

dan apabila setelah ditemukan

kontaminan logam loin dikemas

ulang atau dibuat produk bentuk yang lain apabila sudah tidak memenuhi syarat bentuk loin yang rapi.

t. Penimbangan, Pengemasan dan Pelabelan

Pada tahapan ini potongan (saku cut, cube cut) yang tidak mengandung kontaminan logam dikemas dalam kemasan karton dan ditimbang. Kemasan karton ini dapat berupa innert karton ataupun langsung dikemas dalam master karton sesuai permintaan konsumen.

Selanjutnya, karton diberi label sesuai dengan spesifikasi loin yang dikemas.

u. Penyimpanan

Loin yang telah dikemas dalam karton disimpan di dalam cold storage sebagai gudang penyimpanan beku dengan suhu $-25^{\circ} \mathrm{C}$. Penyusunan karton di dalam cold storage dilakukan sedemikian rupa sehingga dapat memudahkan dalam pembongkaran pada saat tahapan pemuatan/stuffing. Penyusunan karton dilakukan dengan system first in first out yang berarti bahwa produk yang pertama masuk akan menjadi produk yang pertama keluar.

v. Pemuatan

Produk tuna beku dalam bentuk saku cut, cube cut siap dipasarkan, diangkut menggunakan kontainer berpendingin (reefer container) bersuhu $\quad-20 \quad{ }^{\circ} \mathrm{C}$ menuju pelabuhan laut untuk dieksport sebagai tuna beku dengan mutu terbaik.

Data produksi Bulan Januari 2021

Data produksi PT. Maluku Prima Makmur diperoleh berdasarkan hasil produksi dari tanggal 4 Januari 2021 sampai dengan tanggal 16 Januari 2021 adalah sebagai berikut : 
Tabel 3. Data Produksi Bulan Januari 2021

\begin{tabular}{|c|c|c|c|c|c|c|c|c|c|c|c|c|}
\hline \multirow{4}{*}{ No } & \multirow{4}{*}{$\begin{array}{c}\text { Jenis } \\
\text { Produk } \\
\text { Tuna }\end{array}$} & \multicolumn{9}{|c|}{ Data Produksi Bulan Januari 2021} & \multirow{2}{*}{\multicolumn{2}{|c|}{ Total Produksi }} \\
\hline & & \multicolumn{9}{|c|}{ Tanggal Produksi } & & \\
\hline & & 4 & 6 & 8 & 11 & 12 & 13 & 14 & 15 & 16 & & \\
\hline & & $\mathrm{Kg}$ & $\mathrm{Kg}$ & $\mathrm{Kg}$ & $\mathrm{Kg}$ & $\mathrm{Kg}$ & $\mathrm{Kg}$ & $\mathrm{Kg}$ & $\mathrm{Kg}$ & $\mathrm{Kg}$ & $\mathrm{Kg}$ & $\%$ \\
\hline 1 & Bahan Baku & 1,904 & 4,307 & 608 & 8,014 & 6,130 & 632 & 5,396 & 3,861 & 5,059 & 35,911 & 100 \\
\hline 2 & $\begin{array}{l}\text { Produk } \\
\text { Utama }\end{array}$ & 805 & 1,513 & 283 & 4,100 & 3,104 & 320 & 2,575 & 1,560 & 2,399 & 16,659 & 46.39 \\
\hline 3 & $\begin{array}{l}\text { Produks } \\
\text { Sampingan }\end{array}$ & 174 & 393 & 55 & 768 & 561 & 58 & 492 & 353 & 431 & 3,285 & 9.15 \\
\hline 4 & Limbah & 925 & 2,401 & 270 & 3,146 & 2,465 & 254 & 2,329 & 1,948 & 2,229 & 15,967 & 44.46 \\
\hline
\end{tabular}

\section{Hasil pengumpulan data menggunakan}

Tabel Check Sheet

Tabel 4. Check Sheet Bahan Baku, Produk dan Limbah Tuna Loin Bulan Januari 2021

\begin{tabular}{|c|c|c|c|c|c|c|}
\hline \multirow[b]{2}{*}{ No } & \multirow{2}{*}{$\begin{array}{l}\text { Tanggal } \\
\text { Produksi }\end{array}$} & \multicolumn{4}{|c|}{ Jumlah Produksi } & Persentase \\
\hline & & $\begin{array}{l}\text { Bahan } \\
\text { Baku }\end{array}$ & Produk Utama & Produk Sampingan & Limbah Padat & Limbah \\
\hline
\end{tabular}

\begin{tabular}{ccccccc}
\hline 1 & 4 & 1,904 & 805 & 174.34 & 924.66 & $49 \%$ \\
\hline 2 & 6 & 4,307 & 1,513 & 392.79 & $2,401.21$ & $56 \%$ \\
\hline 3 & 8 & 608 & 283 & 55.32 & 269.68 & $44 \%$ \\
\hline 4 & 11 & 8,014 & 4,100 & 767.70 & $3,146.30$ & $39 \%$ \\
\hline 5 & 12 & 6,130 & 3,104 & 561.12 & $2,464.88$ & $40 \%$ \\
\hline 6 & 13 & 632 & 320 & 58.07 & 253.93 & $40 \%$ \\
\hline 7 & 14 & 5,396 & 2,575 & 492.12 & $2,328.88$ & $43 \%$ \\
\hline 8 & 15 & 3,861 & 1,560 & 352.57 & $1,948.43$ & $50 \%$ \\
\hline 9 & 16 & 5,059 & 2,399 & 430.59 & $2,229.41$ & $44 \%$ \\
\hline & Total & 35,911 & 16,659 & 3,285 & 15,967 & $45 \%$ \\
\hline & $\begin{array}{c}\text { Rata- } \\
\text { Rata/unit }\end{array}$ & 3,990 & 1,851 & 365 & 1,774 &
\end{tabular}

Tabel 5. Check Sheet Rata-Rata dan Persentase Komulatif Produk dan Limbah Bulan Januari 2021

\begin{tabular}{llcccccc} 
No & Jenis Produk & $\begin{array}{c}\text { Total } \\
\text { Produk }\end{array}$ & $\begin{array}{c}\text { Rata- } \\
\text { rata }\end{array}$ & Min & Max & Komulatif & \% Komulatif \\
\hline 1 & Produk Utama & 16,659 & 1,851 & 283 & 4,100 & 16,659 & $46 \%$ \\
\hline 2 & Limbah Produk & 15,967 & 1,774 & 254 & 3,146 & 32,626 & $91 \%$ \\
\hline 3 & $\begin{array}{l}\text { Produk } \\
\text { Sampingan }\end{array}$ & 3,285 & 365 & 55 & 3,285 & 35,911 & $100 \%$ \\
\hline
\end{tabular}

35,911 
Identifikasi Produktivitas Pengolahan Tuna Beku

Pada PT. Maluku Prima Makmur di Kota Ambon

Hasil pengumpulan data menggunakan

Histogram

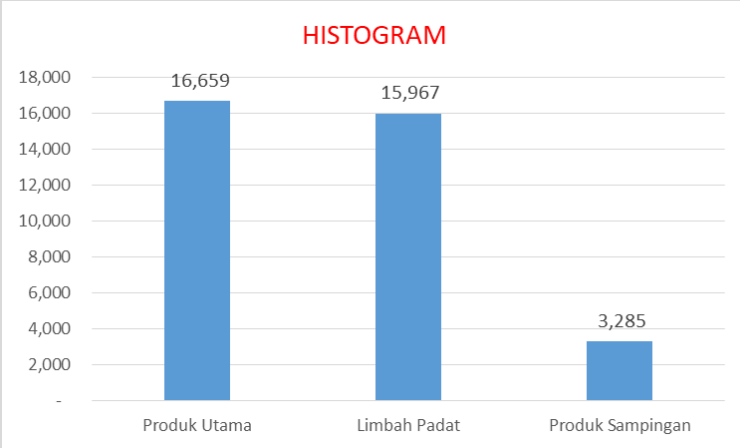

Gambar 2. Histogram Produk dan Limbah Tuna Loin Bulan Januari 2021

Hasil pengumpulan data menggunakan

Peta Kendali $P$

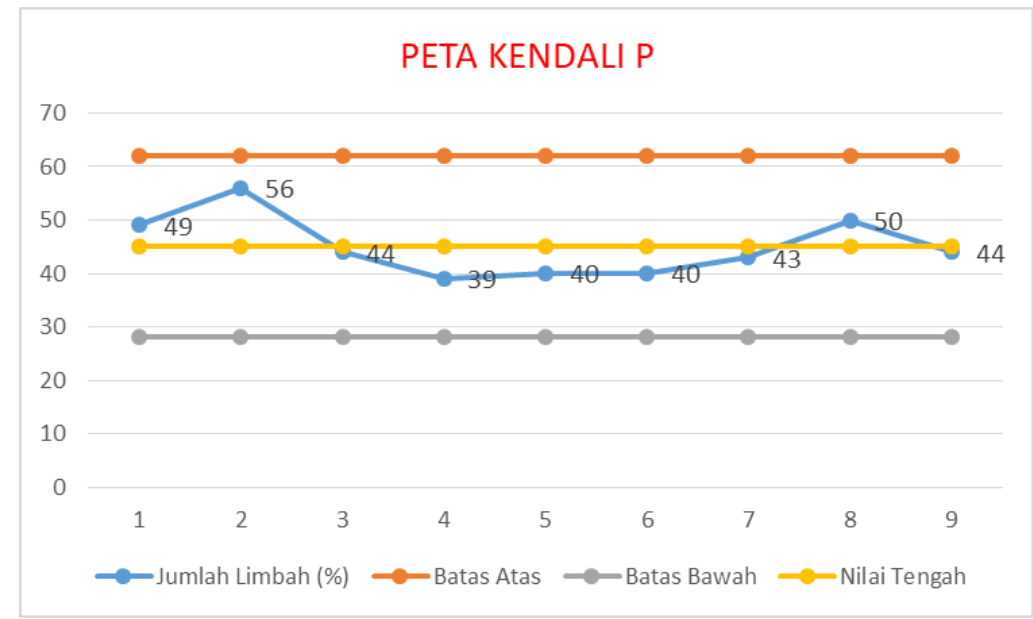

Gambar 3. Peta Kendali P Limbah Prosesing Tuna Beku

Hasil pengumpulan data menggunakan

Diagram Pareto

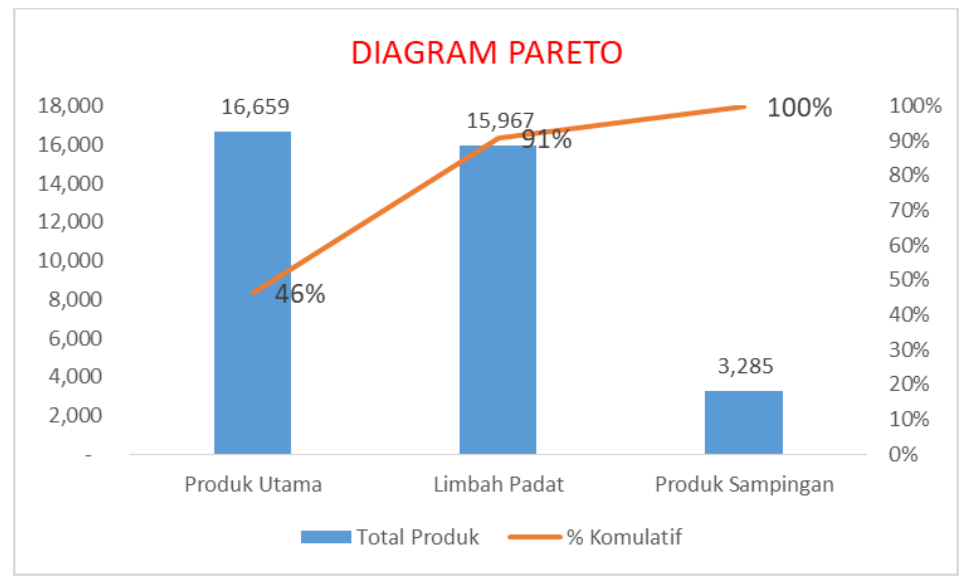

Gambar 4. Diagram Pareto Produk dan limbah Prossing Tuna

Beku 


\section{Pembahasan}

Tahapan Proses Pengolahan Tuna Beku

Berdasarkan acuan Badan

Standardisasi Nasional, (2015), tahapan prosesing tuna loin beku di PT. Maluku Prima Makmur dapat dijelaskan bahwa pada penerimaan bahan baku ikan tuna, suhu pusat tubuh ikan tetap terjaga pada suhu maksimum $4,4^{\circ} \mathrm{C}$.

Pengukuran suhu pusat tubuh ikan tuna pada tahapan penerimaan bahan baku dan setiap tahapan prosesing bertujuan untuk mengetahui penerapan sistem rantai dingin yang dilakukan dan tingkat kesegaran ikan tuna yang akan diproses lebih lanjut. Hasil pengukuran suhu ikan menunjukkan suhu yang tidak melebihi suhu $4,4^{\circ} \mathrm{C}$. Suhu produk tuna dipertahankan dibawah $4,4^{\circ} \mathrm{C}$. Suhu sangat berperan untuk pertumbuhan mikroorganisme. Apabila suhu naik, kecepatan metabolisme dan pertumbuhan dipercepat, apabila suhu turun, kecepatan metabolisme juga turun dan pertumbuhan diperlambat (Effendi, 2009).

Suhu pusat tubuh ikan maksimum $4,4{ }^{\circ} \mathrm{C}$ juga dimaksudkan untuk mencegah terjadinya kenaikan kadar histamin. Menurut hasil penelitian (Price et al., 1991) histamin akan terhambat pembentukannya pada suhu $0{ }^{\circ} \mathrm{C}$ atau lebih rendah. Pada suhu $4,4{ }^{\circ} \mathrm{C}$ terbentuk histamin sebesar 0,5 - 1,5 $\mathrm{mg} / 100$ gram ikan. Konsentrasi tersebut memenuhi aturan SNI yaitu tidak melampaui $5 \mathrm{mg} / 100 \mathrm{gram}$, oleh karena itu (SNI 2729- 2013) menetapkan batas kritis suhu untuk pembentukan histamin pada ikan sebesar $4,4^{\circ} \mathrm{C}$.

Ikan tuna memiliki kandungan kandungan protein dan merupakan bagian terbesar dari gizi yang ada pada tuna. Protein ikan tuna ini terdiri dari asam amino, diantaranya adalah asam amino histidin yang memiliki komposisi paling besar jika dibandingkan dengan jenis ikan lainnya seperti ikan kappa dan mahi - mahi (Antoine et al., 2001)

Asam amino histidin bebas akan diurai menjadi histamin pada suhu lebih dari $4,4^{\circ} \mathrm{C}$ oleh enzim histidin dekarboksilase dan juga oleh bakteri yang berada di dalam ikan tuna itu sendiri seperti bakteri Morganella morganii. Pertumbuhan bakteri dapat dikendalikan dengan melakukan mempertahankan suhu di bawah $4.4^{\circ} \mathrm{C}$, tetapi pembentukan histamin dapat dihentikan dengan penyimpanan beku (Lee et al., 2012).

Akibat yang dapat ditimbulkan apabila mengonsumsi ikan tuna yang mengandung histamin yang melebihi standar adalah gejala sakit dalam waktu singkat berupa memerah pada wajah, leher, dada bagian atas, muntah, berkeringat, kram perut, sakit kepala, diare, mual, 
pusing dan jantung berdebar-debar (EFSA, 2011). Persyaratan kadar histamin pada ikan tuna di setiap negara berbeda (Evangelista et al., 2016). Uni Eropa mensyaratkan kadar histamin maksimum 100 ppm (EC, 2005), Amerika Serikat mensyaratkan kadar histamin maksimum 50 ppm (FDA, 2011), sedangkan Codex Alimentarius mensyaratkan kadar histamin maksimum 200 ppm (FAO, 2012). Sementara, mengacu pada Standar Nasional Indonesia (SNI) tentang persyaratan mutu dan ikan segar (SNI 2729-2013) bahwa kadar histamin yang dipersyaratkan maksimum 100 ppm.

Selain pengukuran suhu pusat tubuh ikan, pengujian mutu secara organoleptik terhadap ikan tuna pada penerimaan bahan baku dilakukan satu persatu meliputi warna, bau, dan konsistensi daging dengan menggunakan alat yang disebut coring tube. Tujuan dari pengujian ini adalah untuk mengetahui mutu dan kesegaran bahan baku, kualitas daging ikan tuna dan grade ikan tuna yang diterima. Data karakteristik dan penerimaan standar penerimaan pada Tabel 2.

Pemberian Gas CO dengan nilai $41.01 \mathrm{mg} \%$ memberikan warna yang dapat diterima berdasarkan penentuan derajat hue yaitu warna merah. Pada Tahapan penyemprotan Gas CO, Penyemprotan Gas CO (karbon monoksida) pada daging ikan tuna dapat mempertahankan warna merah daging ikan tuna selama penyimpanan dan pengangkutan. Menurut Levingston Dj dan Brown WD, 1981 dalam (Loppies et al., 2021), Senyawa gas CO (karbon monoksida) dapat bereaksi dengan myoglobin menjadi senyawa karboksimioglobin yang merupakan bentuk stabil dari pigmen merah dalam daging ikan tuna. Karboksimioglobin dapat mencegah terjadinya proses oksidasi dibanding oksimioglobin karena senyawa karbon monoksida memiliki daya ikat myoglobin yang lebih kuat dibanding oksigen.

Pada tahapan pengemasan vakum, selain memberikan keadaan vakum sehingga loin terhindari dari kemungkinan oksidasi akibat reaksi dengan oksigen, juga memberikan perlindungan terhadap produk loin dari kemungkinan kontaminasi dari luar. Menurut (Nasution et al., 2016), Pengemasan vakum merupakan sistem pengemasan hampa udara dimana tekanan udara kurang dari 1 atm yang dilakukan dengan cara mengeluarkan $\quad \mathrm{O}_{2} \quad$ sehingga memperpanjang umur simpan. 
Pada tahapan pembekuan, ikan tuna diturunkan suhu dengan menggunakan mesin pembeku (Air Blast Freezer) sampai suhu mencapai $\quad-30 \quad{ }^{\circ} \mathrm{C}$. Proses pembekuan dimaksudkan untuk menghentikan aktivitas bakteri dan enzim yang merupakan faktor utama pembusukan ikan.

Pembekuan dimaksudkan untuk mengawetkan sifat-sifat alami ikan. Pembekuan menggunakan suhu yang lebih rendah yaitu jauh dibawah titik beku ikan. Pembekuan mengubah hampir seluruh kandungan air pada ikan menjadi es, tetapi pada waktu ikan beku dilelehkan kembali untuk digunakan, keadaan ikan kembali seperti sebelum dibekukan. Keadaan beku menyebabkan bakteri dan enzim terhambat kegiatannya, sehingga daya awet ikan beku lebih besar dibandingkan dengan ikan yang hanya didinginkan (Murniyati dan Sunarman, 2000).

Pada tahapan pendeteksian logam, pendeteksian dilakukan untuk memeriksa serpihan logam yang mungkin terdapat dalam daging tuna. Penyebab bahaya ini yaitu peralatan prosesing yang terbuat dari logam atau serpihannya yang tertinggal dalam daging tuna termasuk benda-benda atau aksesoris yang digunakan oleh karyawan. Bahaya ini termasuk sebagai bahaya keamanan pangan dan memiliki dampak yang sangat serius, namun peluang terjadinya kontaminan logam ini termasuk kecil karena dapat dikendalikan oleh GMP (Good Manufacturing Practices). Bahaya ini termasuk bahaya signifikan sehingga diperlukan pengontrolan dengan baik. Tindakan pencegahan yang dilakukan yaitu dengan cara deteksi logam pada setiap kemasan yang akan diekspor dan cek sensitivitas mesin setiap jam.

Analisis produktivitas pada bagian prosesing dengan menggunakan metode Kaizen

Berdasarkan data produksi dari tanggal 4 Januari sampai dengan tanggal 16 Januari 2021 analisis produktivitas kinerja bagian prosesing dapat ditentukan dengan metode kaizen dan seven tools untuk mempermudah analisis pada Tabel 1. Data Produksi Bulan Januari 2021, dari bahan baku ikan tuna sebanyak $35.911 \mathrm{~kg}$ diperoleh produk utama sebesar $16.659 \mathrm{Kg}$ $(46,39 \%)$, produk sampingan sebesar $3.285 \mathrm{Kg}$

\%) sedangkan limbah padat hasil prosesing sebesar $15.967 \mathrm{Kg}(44,46$ $\%)$. Selanjutnya dibuat diagram histogram yang merupakan salah satu alat didalam metode perbaikan kualitas yang berfungsi untuk memetakan distribusi atas sejumlah data. Data tersebut diperoleh dari 
tabel check sheet yang terdapat tiga jenis kriteria produk yang dihasilkan dari prosesing tuna loin yang akan didistribusikan datanya. Untuk lebih jelasnya hasil dari distribusi tiga jenis kriteria produk tersebut bisa dilihat pada Gambar 2. Hasil histogram dari Gambar 2 dapat dilihat distribusi jenis produk dan limbah yang dihasilkan yang terjadi selama proses produksi di bulan Januari 2021 adalah produk utama sebanyak 16,659 kg, produk sampingan $3.285 \mathrm{~kg}$ dan limbah sebanyak 15,967 kg. Setelah membuat diagram histogram, langkah selanjutnya yaitu membuat peta kendali $P$ ( $P$ Chart) yang berfungsi untuk melihat apakah pengendalian kualitas yang dilakukan sudah terkendali atau belum. Dari hasil perhitungan dapat dibuat Peta Kendali $P$ yang dapat dilihat pada Gambar 3. Berdasarkan gambar grafik Peta Kendali P diatas dapat dilihat bahwa proporsi limbah padat menunjukan bahwa pada bulan Januari 2021 mempunyai proporsi limbah padat tertinggi yaitu sebesar 2,401.21 kg akan tetapi tidak berada di luar batas kontrol atas (upper control limit). Dengan demikian maka tidak ada hal yang perlu diperbaiki karena tidak ada yang keluar dari batas kendali. Dengan demikian dalam menentukan faktor penyebab yang dominan terhadap masalah kinerja bagian prosesing digunakan Diagram Pareto. Diagram Pareto adalah diagram yang digunakan untuk mengidentifikasi, mengurutkan persentase produk utama, produk sampingan, dan limbah yang dihasilkan dalam suatu proses produksi. Dengan melihat persentase yang terdapat pada Gambar 4 di atas maka dapat dijelaskan bahwa limbah padat memiliki persentase yang tidak berbeda jauh dengan produk utama dimana limbah padat sebesar $15,967 \mathrm{~kg}$ atau $45 \%$ dan produk utama sebesar $16,659 \mathrm{~kg}$ atau $46 \%$, sedangkan produk sampingan hanya sebesar 3,285 $\mathrm{kg}$ atau $9 \%$.

Dengan demikian, bahwa jumlah produk utama dan produk sampingan dari prosesing tuna loin sebesar $55 \%$. Hal ini berarti jumlah produk ikan tuna hasil kinerja bagian prosesing untuk tujuan konsumsi di PT. Maluku Prima Makmur masih memenuhi standar produktivitas.

Menurut Stansby dan Olcott (1963) dalam (Hadinoto \& Idrus, 2018), ikan tuna memiliki bagian tubuh yang dapat dikonsumsi sebesar $50-60 \%$.

Selain produk utama dan produk sampingan dari prosesing tuna loin di PT. Maluku Prima 
Makmur, limbah padat memiliki persentase yang cukup tinggi yaitu $45 \%$ dari total produksi di Bulan Januari. Limbah padat ini berupa tulang, kepala, sirip, dan kulit ikan yang masih bisa dimanfaatkan menjadi produk bernilai ekonomis seperti tepung ikan, gelatin, kolagen, kerupuk kulit, hidroksiapatit, dan lain-lain. Peluang pemanfaatan limbah ikan tuna menjadi produk-produk bernilai tambah yang memiliki nilai jual yang cukup menjanjikan.

Kulit dan tulang ikan dapat dijadikan gelatin. Gelatin adalah hasil dari hirolisat protein dari kulit dan tulang ikan. Gelatin mudah dicerna oleh tubuh manusia, mempunyai sifat rendah kalori, protein tinggi, serta bebas kandungan gula. Gelatin dapat diaplikasikan dengan mudah untuk keperluan industri pangan, fotografi, dan farmasi (Agustin, 2013). Produk tulang ikan berupa hidroksiapatit $\mathrm{Ca}_{5}\left(\mathrm{PO}_{4}\right)_{3}(\mathrm{OH})$ merupakan unsur anorganik alami yang berasal dari tulang yang dapat dimanfaatkan untuk regenerasi tulang, memperbaiki, mengisi, memperluas dan merekonstruksi jaringan tulang. Hal ini dikarenakan hidroksiapatit memiliki sifat biokompatibiltas yang sempurna apabila diimplankan pada tulang. Selain itu, hidroksiapatit juga dapat digunakan sebagai adsorben untuk mengatasi pencemaran lingkungan terhadap logam berat (Aisyah et al., 2012). Kulit ikan merupakan salah satu biota yang dapat dimanfaatkan sebagai bahan baku penghasil kolagen. Kolagen dapat diekstraksi secara kimiawi maupun kombinasi antara proses kimiawi dan enzimatis (Mutmainnah et al., 2017).

\section{SIMPULAN DAN SARAN}

\section{SIMPULAN}

Berdasarkan hasil analisis dengan menggunakan data primer, sekunder, dan analisis data menggunakan Metode Kaizen maka dapat disimpulkan sebagai berikut :

1. Proses pengolahan tuna Beku di PT. Maluku Prima Makmur adalah sebagai berikut: Penerimaan bahan baku ikan tuna tanpa Insang dan isi perut, Penimbangan 1, Pencucian 1, Penyimpanan Sementara, Pencucian 2, Pemotongan Kepala ,Pencucian 3, Pemotongan Loin, Pembuangan kulit dan Perapihan, Potong (Saku, Cube Cut), Pengemasan 1, Penyemprotan Gas CO, Pendinginan, Penyedotan $\mathrm{CO}$, Sortasi dan sizeing, Pengemasan plastik vakum, Penimbangan 2, Pemvaccuman, Pembekuan, Pendeteksian Logam (Metal Detection), Penimbangan Pengepakan \& 
Pelabelan, Penyimpanan Beku,

Pemuatan.

2. Limbah padat hasil prosesing tuna loin berupa kepala, tulang dan kulit belum dimanfaatkan sebagai produk bernilai tambah. Berdasarkan perhitungan data produksi di bulan Januari 2021 diperoleh jumlah limbah padat yang dibuang sebesar $15,967 \mathrm{Kg}$ (45 $\%)$.

3. Produktivitas kinerja bagian prosesing tuna beku pada PT. Maluku Prima Makmur masih memenuhi standar produktivitas.

\section{SARAN}

Perlu adanya kajian lebih lanjut guna pemanfaatan limbah padat sehingga dapat diolah menjadi produk bernilai ekonomis seperti tepung tulang ikan, gelatin, kolagen, hidoksiapatit, kerupuk, produkproduk bioteknologi dan lain-lain.

\section{PERSANTUNAN}

Ucapan terima kasih disampaikan kepada PT. Maluku Prima Makmur di Kota Ambon yang telah ngijinkan penulis melakukan penelitian di lokasi tersebut.

\section{DAFTAR PUSTAKA}

[BSN] Badan Standardisasi Nasional. (2013). SNI 2729:2013 Ikan Segar. Badan
Standarisasi Nasional, 1-15.

[BSN] Badan Standardisasi Nasional. (2015). SNI 4104: 2015. Tuna Loin Beku. Dewan SNI.

Agustin, A. T. (2013). Gelatin Ikan: Sumber, Komposisi Kimia dan Potensi Pemanfaatannya. Media Teknologi Hasil Perikanan, 1(2), 44-46. https://doi.org/10.35800/mthp.1. 2.2013.4167

Aisyah, D., Mamat, I., Rosufila, Z., \& Ahmad, N. M. (2012). Program Pemanfaatan Sisa Tulang Ikan Untuk Produk Hidroksiapatit: Kajian Di Pabrik Pengolahan Kerupuk Lekor Kuala Trengganu-Malaysia. Jurnal Sosioteknologi, 11(26), 116125-125.

Antoine, F. R., Wei, C. I., Littell, R. C., Quinn, B. P., Hogle, A. D., \& Marshall, M. R. (2001). Free amino acids in dark- and whitemuscle fish as determined by 0 phthaldialdehyde precolumn derivatization. Journal of Food Science, 66(1), 72-77. https://doi.org/10.1111/j.13652621.2001.tb15584.x

EC, 2005. (2005). [EC] European Commission. (2005).

Regulation (EC) No.2073/2005 of 15 November 2005 on microbiological criteria for foodstuffs. Official Journal of the European Union. L 338/1. Official Journal of the European Union. L 322/12.

Effendi, S. (2009). Teknologi Pengolahan dan Pengawetan Pangan. CV. ALFABETA.

EFSA. (2011). [EFSA] European Food Safety Authority. (2011). Scientific opinion on risk based control of biogenic amine formation in fermented foods. [EFSA] European Food Safety Authority, 9(10), 1-93. https://doi.org/10.2903/j.efsa.20 
11.2393

Evangelista, W. P., Silva, T. M., Guidi, L. R., Tette, P. A. S., Byrro, R. M. D., Santiago-Silva, P., Fernandes, C., \& Gloria, M. B. A. (2016). Quality assurance of histamine analysis in fresh and canned fish. Food Chemistry, 211, 100-106. https://doi.org/10.1016/j.foodch em.2016.05.035

FAO. (2012). [FAO] Food Agricultural Organization of the United Nations. (2012). Codex alimentarius Commission. Joint FAO/WHO Food standar programme. Codex committee on fish and fishery products, 32 session discussion paper histamine, 1-14. Food Agricultural Organization of the United Nations.

FDA. (2011). Fish and Fishery Products Hazards and Controls Guidance. Fish and Fishery Products Hazard and Control Guidance Fourth Edition, April, $1-401$.

https://doi.org/10.1039/9781847 558398-00136

Hadinoto, S., \& Idrus, S. (2018). Proporsi dan Kadar Proksimat Bagian Tubuh Ikan Tuna Ekor Kuning (Thunnus albacares) Dari Perairan Maluku. Majalah BIAM, 14(2). https://doi.org/10.29360/mb.v14 i2.4212

Lee, Y. C., Kung, H. F., Lin, C. Saint, Hwang, C. C., Lin, C. M., \& Tsai, Y. H. (2012). Histamine production by Enterobacter aerogenes in tuna dumpling stuffing at various storage temperatures. Food Chemistry, 131(2), 405-412. https://doi.org/10.1016/j.foodch em.2011.08.072

Loppies, C. R. M., Apituley, D. A. N., \& Sormin, R. B. D. (2021). Content of Tuna Loin ( Thunnus albacores ) Treated by Carbon Monoxide and Filtered Smoke
During Stored. Jurnal Teknologi Hasil Perikanan, 1.

Murniyati, A. S., \& Sunarman, D. (2000). Pendinginan, Pembekuan, dan Pengawetan Ikan. Yogyakarta (ID): Kanisius.

Mutmainnah, M., Chadijah, S., \& Rustiah, W. O. (2017). Hidroksiapatit dari Tulang Ikan Tuna Sirip Kuning (Tunnus albacores) dengan Metode Presipitasi. Al-Kimia, 5(2), 119126. https://doi.org/10.24252/alkimia.v5i2.3422

Nasional, $\quad[B S N] \quad B a d a n$ Standardisasi. (2006). Tuna Loin Mentah Beku Bagian 1. SNI 01-4104.1-2006.

Nasution, Z., Ilsa, M., \& Sari, I. N. (2016). Study Vacuum and Non Vacuum Packaging on The Quality Of The Fish Balls Malong (Muarenesox talabon) During Cold Storage Temperature $( \pm 5 \circ C)$.

PRICE, R. J., MELVIN, E. F., \& BELL, J. W. (1991). Postmortem Changes in Chilled Round, Bled and Dressed Albacore. Journal of Food Science, 56(2), 318-321. https://doi.org/10.1111/j.13652621.1991.tb05270.x

Statistik KKP, 2020. (n.d.). Data Produksi Tuna tahun 2019 di Provinsi Maluku. https://statistik.kkp.go.id/home.p $\mathrm{hp} ? \mathrm{~m}=$ total $\& \mathrm{i}=2$ 